JURNAL CEMERLANG: Pengabdian pada Masyarakat ISSN 2654-4741

Vol. 1, No. 1, 2018, $90-100$

DOI: https://doi.org/10.31540/jpm.v1i1.165

\title{
DESTILASI AIR LAUT DENGAN MEMANFAATKAN PANAS MATAHARI MENGGUNAKAN REFLEKTOR CERMIN CEKUNG UNTUK MEMENUHI KEBUTUHAN AIR DI DESA RANGAI TRITUNGGAL LAMPUNG SELATAN
}

\author{
Guna Bangun Persada, Setiadi Wira Buana, Monna Rozana, Rishal Asri, \\ Koko Friansa, Jabosar Ronggur Hamonangan Panjaitan \\ Institut Teknologi Sumatera, Indonesia
}

\begin{abstract}
ABSTRAK
Provinsi Lampung memiliki garis pantai yang cukup panjang yaitu sekitar $81.000 \mathrm{~km}$. Namun,pasokan air bersih di wilayah pesisir pantai sangatlah terbatas terutama pada daerah-daerah yang padat penduduk.Pengabdian kepada masyarakat ini bertujuan untuk mengatasi permasalahan air bersih di daerah pesisir masyarakat Desa Rangai Tri Tunggal, Lampung Selatan.Metode penentuan perumusan masalah dilakukan dengan metode observasi dan wawancara warga di Desa Rangai Tri Tunggal, Lampung Selatan.Pada pengabdian kepada masyarakat ini, kami membuat alat destilasi air laut untuk memperoleh air tawar berupa alat reflektor cermin cekungyang memanfaatkanpanas energi matahari.Reflektor cermin cekung memiliki diameter 1,8 meter, tinggi cermin $0,4 \mathrm{~m}$ dan titik fokusnya $0,45 \mathrm{~m}$. Reflektor cermin cekung diletakkan di atas tanah dan disinari langsung matahari. Kolektor yang berisi sampel air laut diletakkan diatas reflektor tepat pada posisi titik fokus untuk melakukan proses destilasi. Waktu pengamatan penggunaan reflektor cermin dilakukan selama 7 hari pada cuaca cerah dan dimulai pukul 8 pagi hingga 4 sore. Dari pengamatan yang dilakukan dihasilkan temperatur maksimum suhu destilasi air laut yang didapat menggunakan reflektor cermin cekung adalah $79,4^{\circ} \mathrm{C}$ dengan hasil destilasi air tawar diperoleh rata - rata sebesar $508 \mathrm{ml}$ dari volume awal air laut sebesar 2 liter.
\end{abstract}

KEYWORDS

Destilasi, air laut, daerah pesisir, reflektor, kolektor energi panas matahari

\section{ARTICLE HISTORY}

Received 24 November 2018

Revised 10 December 2018

Accepted 19 December 2018

CORRESPONDENCE Jabosar R.H. Panjaitan@ jabosarronggur@gmail.com 


\section{JURNAL CEMERLANG: Pengabdian pada Masyarakat}

ISSN 2654-4741

Vol. 1, No. 1, 2018, $90-100$

DOI: https://doi.org/10.31540/jpm.v1i1.165

\section{PENDAHULUAN}

Provinsi Lampung memiliki garis pantai yang cukup panjang yaitu sekitar $81.000 \mathrm{~km}$. Namun untuk kebutuhan air besih di wilayah pesisir sangatlah terbatas terutama pada daerah-daerah yang padat penduduk dikarenakan kondisi lingkungan yang kurang mendukung. Krisis air tawar untuk air minum biasanya dialami oleh sebagian besar masyarakat pesisir, terutama di pulau-pulau kecil dan terpencil. Hal ini dapat disebabkan karena sebagian besar air di bumi merupakan air asin terutama daerah pesisir sehingga tidak dapat digunakan secara langsung untuk konsumsi. Distribusi air di dunia menunjukkan bahwa 97,3\% berupa air laut dan sisanya berupa air tawar yang tidak dapat dimanfaatkan karena dalam bentuk gunung es $2,1 \%$ dan hanya sekitar $0,6 \%$ yang dapat dimafaatkan secara langsung (Efendi, 2003).

Desa Rangai Tritunggal didaerah Lampung Selatan merupakan desa para nelayan yang terletak di daerah pesisir Lampung Selatan. Pada umumnya mata pencarian penduduk desa Rangai Tritunggal adalah sebagai nelayan dan penjual ikan. Dari hasil observasi dan wawancara kepada kepala desa, kepala dusun dan masyarakat desa Rangai Tritunggal diketahui bahwa permasalahan warga pesisir di desa Rangai Tritunggal adalahmasalah dalam pemenuhan kebutuhan air bersih untuk keperluan sehari-hari.Saat ini air bersih yang didapat diperoleh dari air sumur bor yang berlokasi cukup jauh dari daerah pesisir desa Rangai Tritunggal sehingga untuk sampai kerumahwarga menggunakan pipa atau selang.Selain itu, kendala yang dihadapi juga terjadipada musim kemarau karena persediaan sumber air bersih akan semakin menipis. Oleh sebab itu, perlu adanya alternatif sumber air bersih lain yang bisa dimanfaatkan oleh warga desa Rangai Tritunggal, salah satunya adalah dengan mendestilasi air laut menjadi air tawar.

Pada pengabdian masyarakat ini dilakukan destilasi air laut dengan cara penguapan menggunakan energi panas matahari dari pemantulan cermin cekung. Kondisi daerah pesisir yang memungkinkan energi radiasi matahari pada musim kemarau dan ketersediaan air laut yang cukup dapat menjadi solusi alternatif permasalahan kelangkaan air (Akhirudin, 2008). Penelitian yang dilakukan 
JURNAL CEMERLANG: Pengabdian pada Masyarakat ISSN 2654-4741

Vol. 1, No. 1, 2018, 90 - 100

DOI: https://doi.org/10.31540/jpm.v1i1.165

Prasetyo (2011) mengatakan bahwa unjuk kerja destilator menggunakan reflektor memiliki hasil destilasi empat kali lebih tinggi daripada destilator tanpa menggunakan reflektor. Suhu maksimum yang didapat menggunakan reflektor adalah $84^{\circ} \mathrm{C}$ dan suhu maksimum yang didapat tanpa menggunakan reflektor adalah $65^{\circ} \mathrm{C}$. Tujuandari pengabdian kepada masyarakat ini adalah pemanfaatan energi panas matahari untuk mendestilasi air laut di daerah pesisir dengan menggunakan reflektor cermin cekung yang diharapkan dapat menghasilkan air tawar secara kontinu.

\section{METODE PELAKSANAAN}

\section{Lokasi dan Waktu Kegiatan}

Pelaksanaan pengabdian kepada masyarakat dilakukan dari bulan Maret Agustus 2018 di daerah pesisir Desa Rangai Tritunggal, Katibung, Lampung Selatan.

\section{Alat dan Bahan}

Alat dan bahan yang digunakanantara lain besi behel $8 \mathrm{~mm}$, alat las, lem kaca, gergaji, pipa besi, plat besi, cermin, wadah sampel air laut,gerinda, selang/pipa,kasa jaring, gelas ukur, termometer, solar power meter.

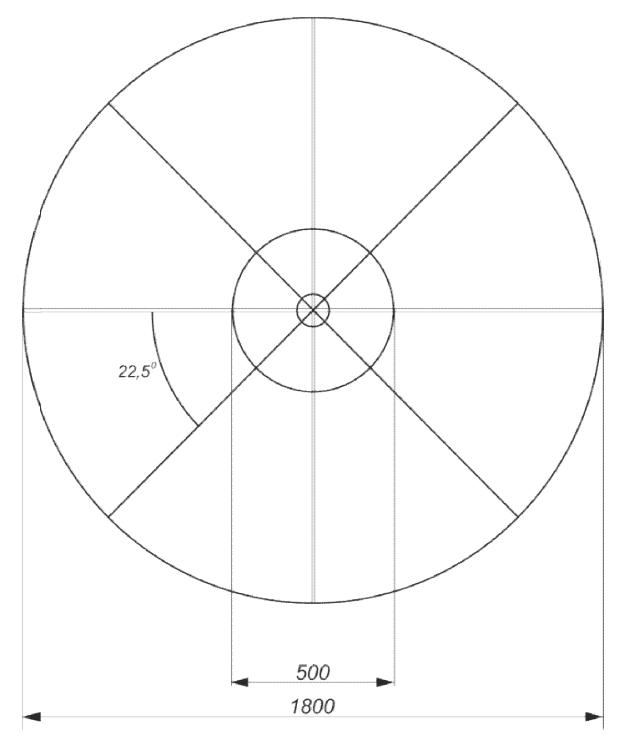

Gambar 1. Desain Reflektor Cermin Cekung (Tampak Atas)

https://ojs.stkippgri-lubuklinggau.ac.id/index.php/JPM 
JURNAL CEMERLANG: Pengabdian pada Masyarakat ISSN 2654-4741

Vol. 1, No. 1, 2018, $90-100$

DOI: https://doi.org/10.31540/jpm.v1i1.165

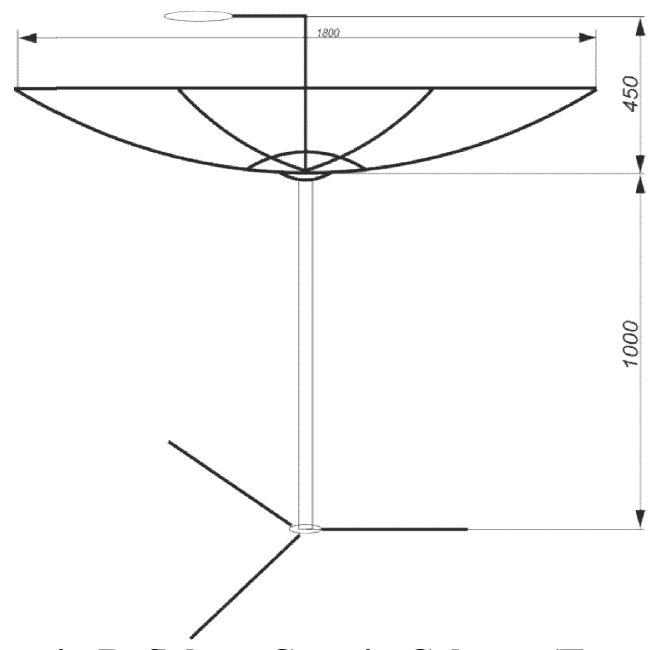

Gambar 2. Desain Reflektor Cermin Cekung (Tampak Samping)

\section{Parameter yang diukur}

Penelitian ini menggunakan reflektor cermin cekung. Parameter yang diukur pada saat pengujian adalah suhu lingkungan, suhu titik api, suhu sampel air laut, suhu penutup kaca, volume awal destilasi dan volume hasil destilasi.

\section{Metode pendekatan kepada masyarakat}

Metode pendekatan kepada masyarakat desa Rangai Tritunggal metode diskusi, konsultasi dan sosialisasi.Metode diskusi dilakukan terhadap kepala desa setempat tentang permasalahan air bersih yang dihadapi dan cara mengatasinya terutama pada saat musim kemarau. Kemudian metode konsultasi dilakukan kepada warga agar dapat menyampaikan informasi tentang solusi pemanfaatan destilasi air laut. Tahap sosialisasi dilakukan dengan mengajak para warga terutama para nelayan membantu membuat, merakit sertamaintenance alat destilasi air laut sederhana yang nantinya akan dipakai secara kontinu. Pada tahap sosialiasi ini kami juga membuat pre-test dan post-tes untuk mengukur pemahaman dan antusias warga.

\section{HASIL DAN PEMBAHASAN}

\section{Fabrikasi dan perakitan reflektor cermin cekung}

Rangka Reflektor terbuat dari besi behel $8 \mathrm{~mm}$ dan dibentuk menyerupai parabola dengan proses bending. Bending merupakan pengerjaan dengan cara memberi tekanan pada bagian tertentu sehingga besi dapat di bengkokkan. Setelah proses bending, besi kemudian di las sedemikian rupa sehingga rangka parabola terbentuk dan dipasang kasa aluminium.Untuk memudahkan proses pemasangan 
JURNAL CEMERLANG: Pengabdian pada Masyarakat ISSN 2654-4741

Vol. 1, No. 1, 2018, $90-100$

DOI: https://doi.org/10.31540/jpm.v1i1.165

dan pelepasan, rangka reflektor yang berbentuk parabola dibagi menjadi 4 bagian yang di bongkar pasang.

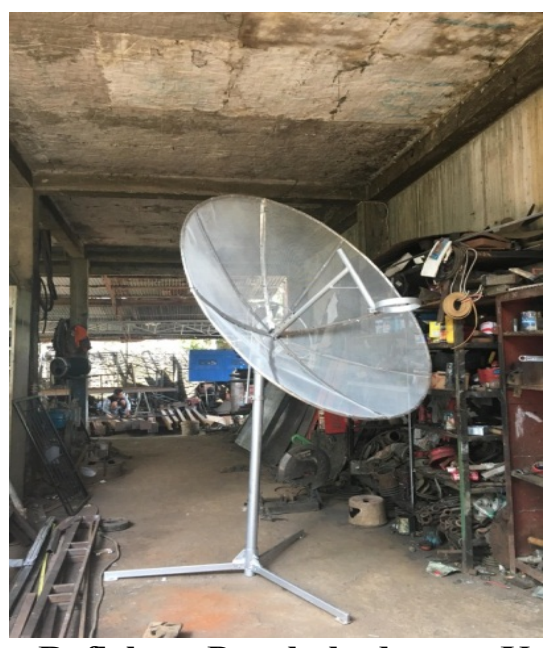

Gambar 3. Kerangka Reflektor Parabola dengan Kasa Alumulium yang Sudah Terpasang

Setelah rangka reflektor parabola selesai di fabrikasi, maka tahap selanjutnya adalah pemasangan cermin pada rangka parabola, kaca cermin yang digunakan adalah cermin datar dengan tebal $3 \mathrm{~mm}$ yang dipotong berbentuk persegi dan disusun sedemikian rupa dan ditempel menggunakan lem kaca sehingga menutupi area cekung pada rangka parabola.
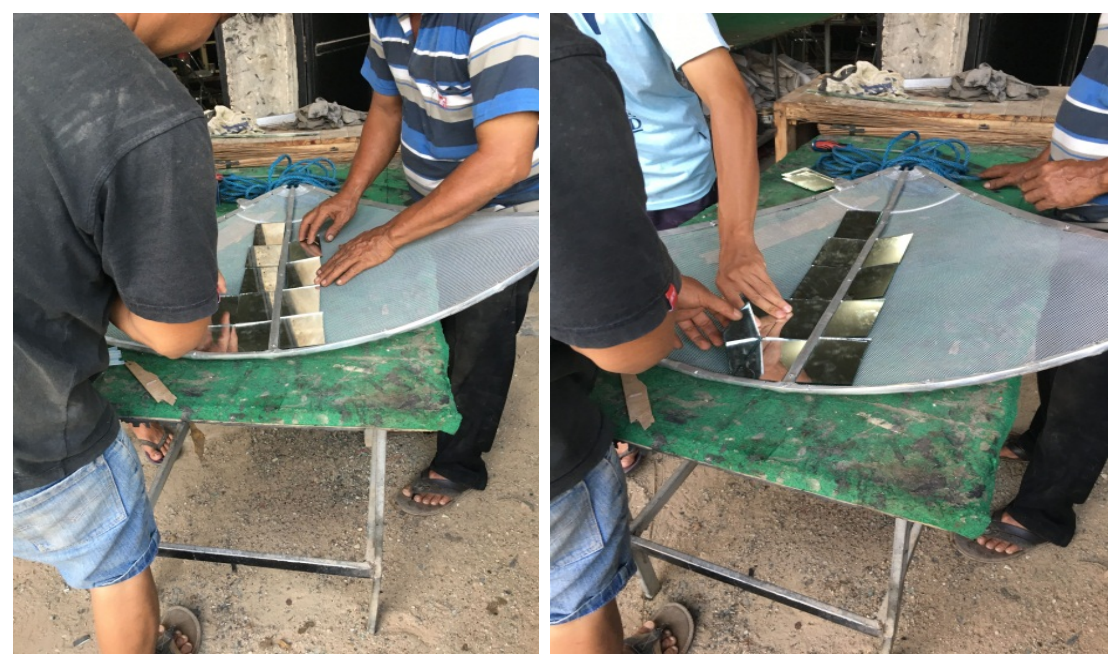

Gambar 4. Pemasangan Cermin pada Rangka Parabola

https://ojs.stkippgri-lubuklinggau.ac.id/index.php/JPM 
JURNAL CEMERLANG: Pengabdian pada Masyarakat ISSN 2654-4741

Vol. 1, No. 1, 2018, $90-100$

DOI: https://doi.org/10.31540/jpm.v1i1.165

Bejana/Tangki penampungan air laut terbuat dari plat aluminium dengan volume 2 liter, memiliki tutup dari kaca, sisi nya dibuat seperti talang untuk mengalirkan air yang menempel di tutup kaca sehingga air bisa mengalir ke saluran selang yang ditampung ke dalam gelas.
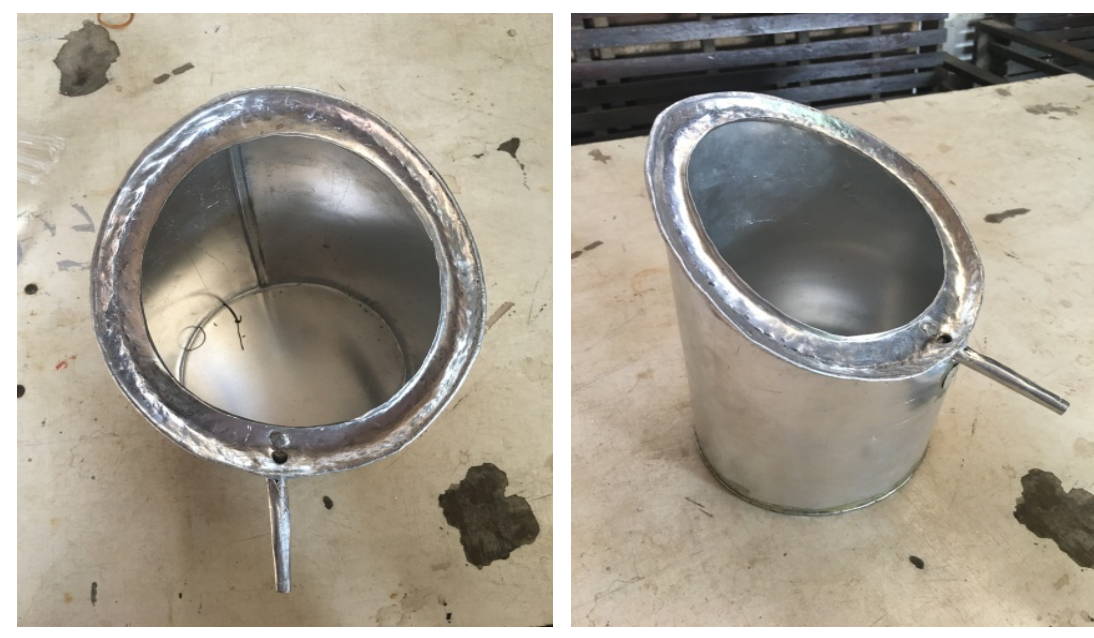

Gambar 5. Pembuatan Bejana/Tanki Air Laut
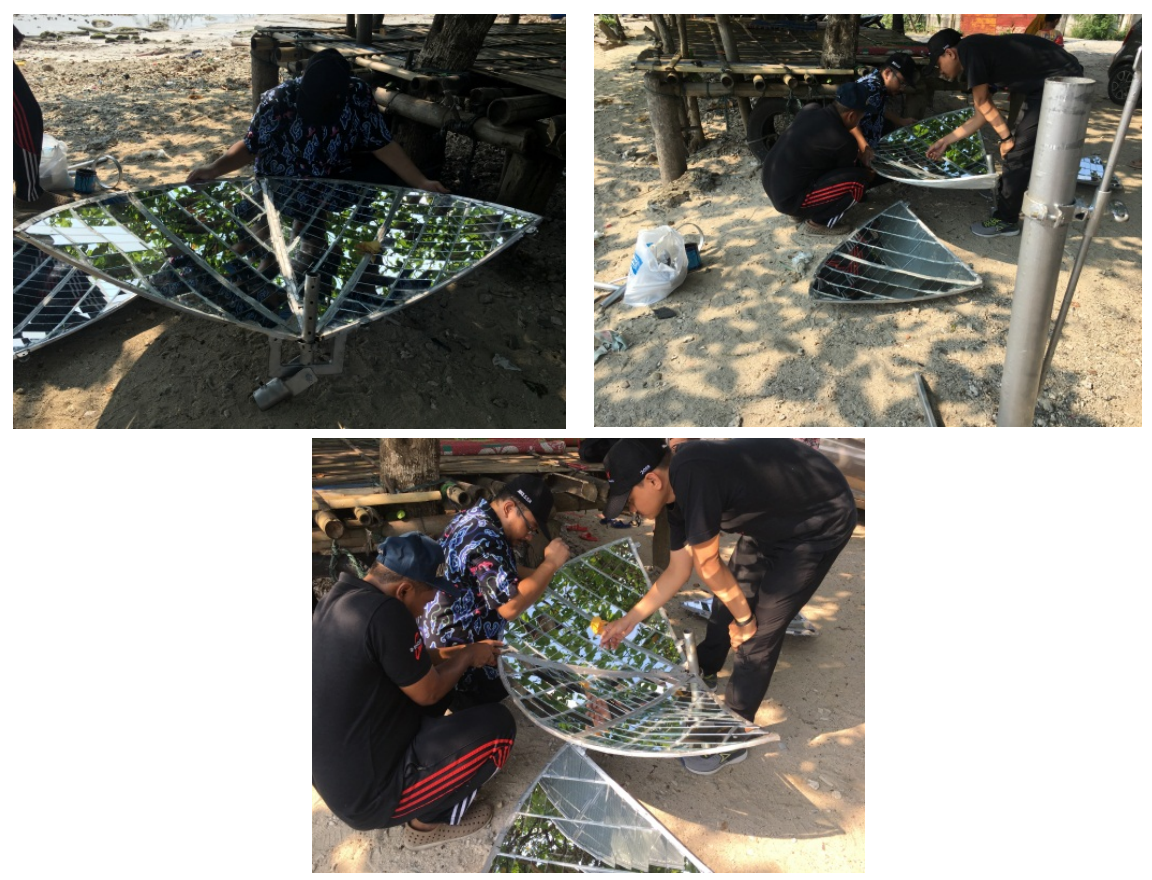

Gambar 6. Pemasangan/Perakitan Reflektor Parabola

https://ojs.stkippgri-lubuklinggau.ac.id/index.php/JPM 
JURNAL CEMERLANG: Pengabdian pada Masyarakat ISSN 2654-4741

Vol. 1, No. 1, 2018, $90-100$

DOI: https://doi.org/10.31540/jpm.v1i1.165

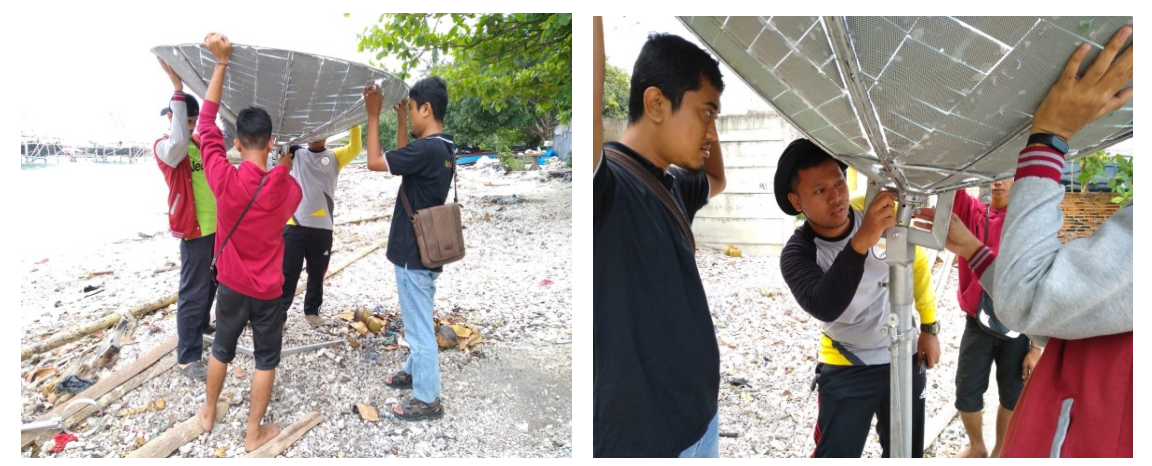

Gambar 7. Pemasangan/Perakitan Kaki-kaki/Tripod.

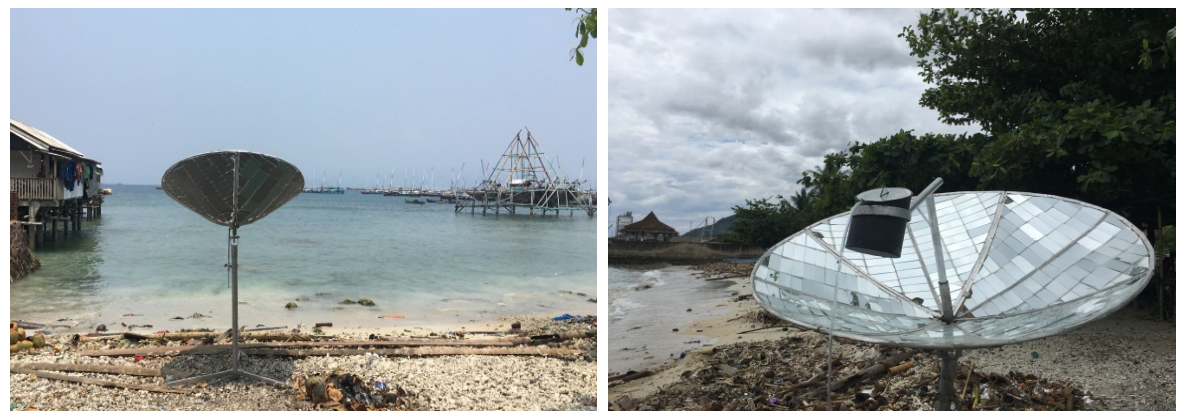

Gambar 8. Destilator yang Sudah Terpasang

\section{Analisis destilasi reflektor cermin cekung}

Sebelum melakukan penelitian destilasi, mula-mula dilakukan pengukuran temperatur lingkungan dan potensi energi sinar matahari di lokasi pengambilan data tersebut. Dengan menggunakan Solar Power Meter potensi cahaya matahari di tepi pantai yaitu sekitar $1049-1158 \mathrm{Watt} / \mathrm{m}^{2}$.
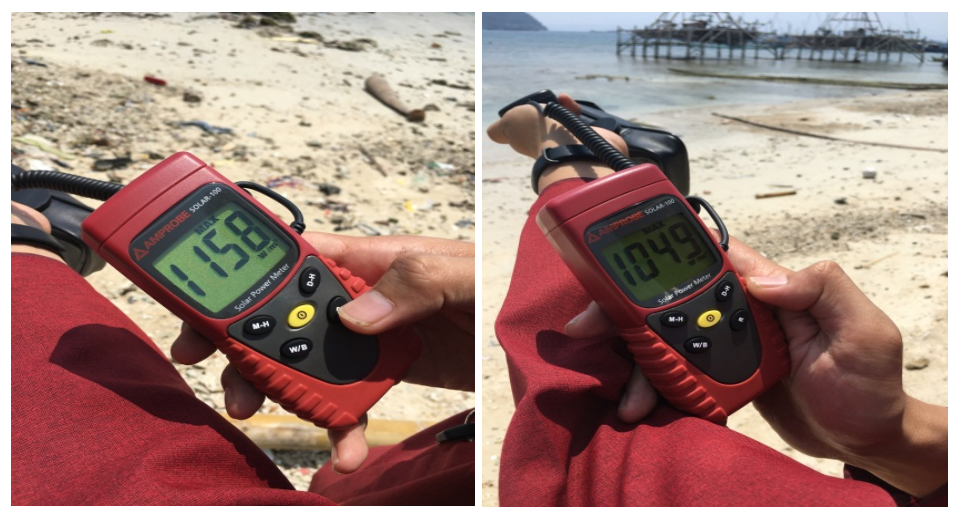

Gambar 9. Pengukuran Potensi Cahaya Matahari Menggunakan Solar Power Meter

https://ojs.stkippgri-lubuklinggau.ac.id/index.php/JPM 
JURNAL CEMERLANG: Pengabdian pada Masyarakat ISSN 2654-4741

Vol. 1, No. 1, 2018, $90-100$

DOI: https://doi.org/10.31540/jpm.v1i1.165

Tabel 1. Data Hasil Destilasi

\begin{tabular}{|c|c|c|c|c|c|c|}
\hline No & Waktu (WIB) & $\mathrm{TL}\left({ }^{\circ} \mathrm{C}\right)$ & $\mathrm{TTA}\left({ }^{\circ} \mathrm{C}\right)$ & $\mathrm{TAL}\left({ }^{\circ} \mathrm{C}\right)$ & $\mathrm{TPK}\left({ }^{\circ} \mathrm{C}\right)$ & $\mathrm{HD}(\mathrm{ml})$ \\
\hline 1 & 08.00 & 28.8 & 34 & 27.3 & 27.4 & - \\
\hline 2 & 09.00 & 33.2 & 68 & 47.8 & 48.8 & 20.8 \\
\hline 3 & 10.00 & 37.7 & 86 & 68.7 & 70.2 & 54.1 \\
\hline 4 & 11.00 & 41.7 & 88 & 78.7 & 80.2 & 82.5 \\
\hline 5 & 12.00 & 41.5 & 88 & 79.4 & 83.4 & 90.3 \\
\hline 6 & 13.00 & 41.5 & 84 & 73.5 & 83.4 & 87.1 \\
\hline 7 & 14.00 & 41.2 & 84 & 73.5 & 78.6 & 85.2 \\
\hline 8 & 15.00 & 35.3 & 64 & 60.2 & 72.7 & 57.1 \\
\hline 9 & 16.00 & 33.6 & 44 & 60 & 68.5 & 30.9 \\
\hline 10 & \multicolumn{6}{|c|}{ Volume Awal } \\
\hline 11 & \multicolumn{7}{|c|}{ Dolume Destilasi } & $2000 \mathrm{ml}$ \\
\hline
\end{tabular}

Keterangan:

TL : Temperatur Lingkungan

TTA : Temperatur Titik Api

TAL : Temperatur Air Laut

TPK : Temperatur Penutup Kaca

HD : Air Hasil Destilasi

Volume air tawar hasil destilasi terbanyak dihasilkan sekitar pukul 11.0013.00 WIB (82,5; 90,3; dan 87,1 ml) seperti yang terlihat pada Tabel 1 dengan volume awal air laut adalah 2 Liter $(2000 \mathrm{ml})$ dengan volume air tawar tertinggi rata-rata sebesar $86,93 \mathrm{ml}$. Total volume yang didapat dalam setu hari adalah 508 $\mathrm{ml}$. Faktor yang mempengaruhi hasil destilasi adalah temperatur pada sampel air laut. Tabel 1 menunjukkan semakin besar temperatur sampel air laut maka hasil destilasi yang dihasilkan juga semakin banyak. Temperatur sampel air laut yang tinggi akan menyebabkan pergerakan molekul air laut semakin cepat sehingga terjadi tumbukan antar molekul yang menyebabkan semakin cepatnya proses perpindahan wujud dari cairan ke gas sehingga terjadi penguapan.

Temperatur tertinggi pada proses destilasi diperoleh pada suhu titik api karena pada daerah ini radiasi matahari yang diterima permukaan reflektor cermin cekung dikumpulkan secara maksimal. Semakin besar radiasi energi matahari yang diterima, maka temperatur titik api pun semakin besar pula. Temperatur pada 
JURNAL CEMERLANG: Pengabdian pada Masyarakat ISSN 2654-4741

Vol. 1, No. 1, 2018, $90-100$

DOI: https://doi.org/10.31540/jpm.v1i1.165

sampel air laut naik seiring dengan besarnya radiasi energi matahari yang diterima.

\section{Sosialisasi Kepada Masyarakat}

Sosialisasi destilasi air laut menggunakan reflektor cermin cekung dilakukan kepada masyarakat bertujuan untuk menginfokan warga perihal energi matahari,fungsi dan cara kerja dari alat destilasi air. Warga yang dikumpulkan berjumlah sekitar 30 orang. Berdasarkan perbandingan hasil pre-tes dan post-tes diperoleh bahwa antusias dan pemahaman warga cukup baik mengenai kegunaan destilasi air laut menggunakan reflektor cermin cekung.
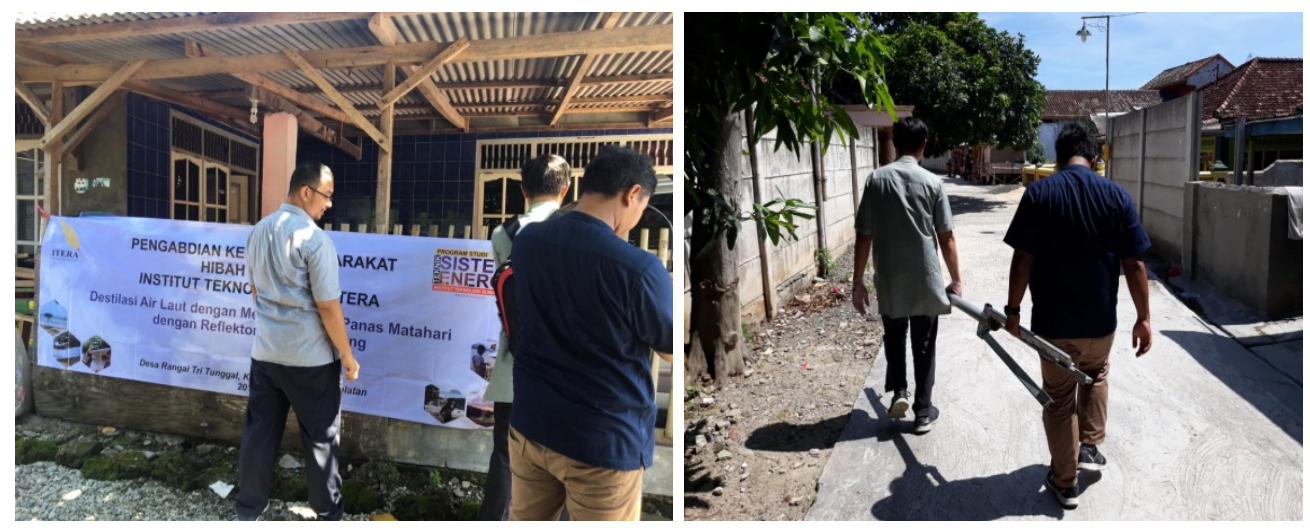

Gambar 10. Persiapan Sosialisasi kepada Masyarakat

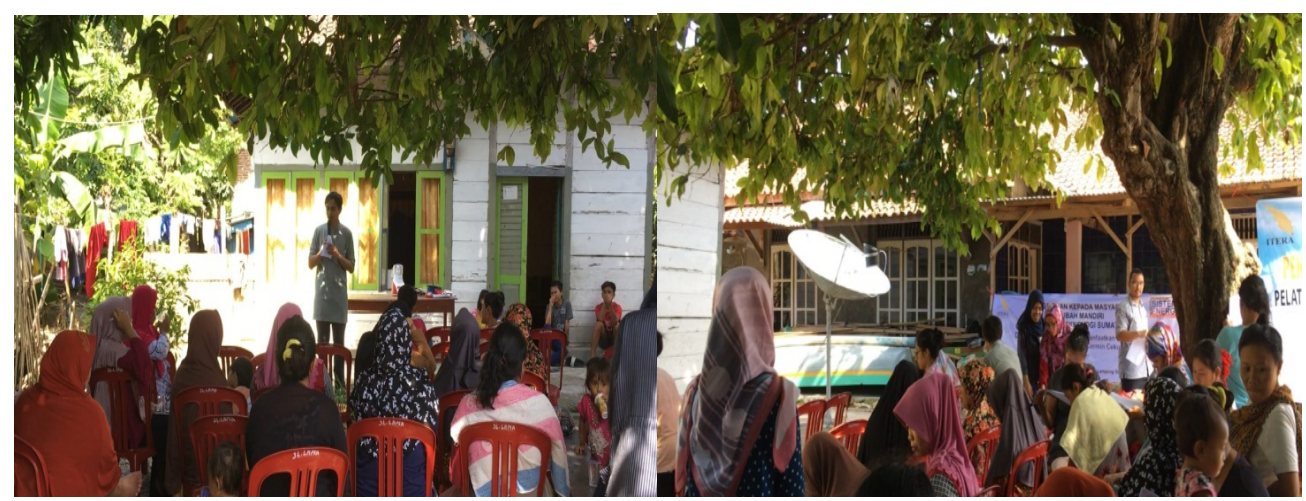

Gambar 11. Sosialisasi kepada Masyarakat Desa Rangai Tri Tunggal 
JURNAL CEMERLANG: Pengabdian pada Masyarakat ISSN 2654-4741

Vol. 1, No. 1, 2018, 90 - 100

DOI: https://doi.org/10.31540/jpm.v1i1.165
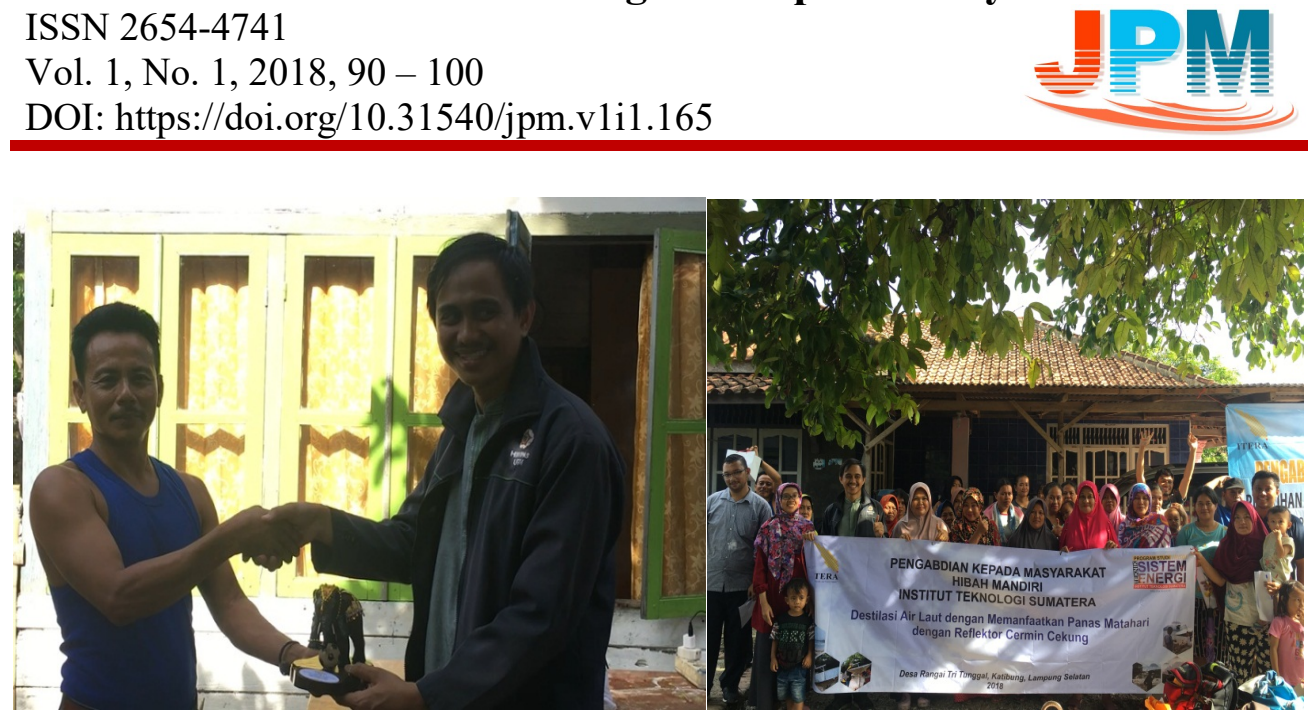

Gambar 12. Penyerahan Kenang-kenangan dan Foto Bersama

\section{SIMPULAN}

Kesimpulan yang didapat dari kegiatan pengabdian masyarakat ini antara lain:

1. Alat Destilasi menggunakan reflektor parabola cermin cekung merupakan alatportable yang memiliki kemudahan dalam proses pemasangan dan pemindahan.

2. Temperatur destilasi maksimum pada sampel air laut yang dipanaskan menggunakan reflektor cermin cekung adalah $79,4^{\circ} \mathrm{C}$ dengan temperatur maksimum pada titik fokus sebesar $88^{\circ} \mathrm{C}$.

3. Hasil destilasi air tawardengan metode pemanasan menggunakan reflektor parabola cermin cekung dihasilkan rata-rata harian sebesar $508 \mathrm{ml}$ dari volume air laut awal sebanyak 2 liter.

4. Dengan melihat potensi daerah pesisir yang kaya akan air laut tidak menutup kemungkinan bahwa air laut bisa dimanfaatkan sebagai sumber air tawar layak konsumsi menggunakan prinsip destilasi reflektor parabola cermin cekung. 
JURNAL CEMERLANG: Pengabdian pada Masyarakat ISSN 2654-4741

Vol. 1, No. 1, 2018, $90-100$

DOI: https://doi.org/10.31540/jpm.v1i1.165

\section{DAFTAR PUSTAKA}

Akhirudin, T. (2008). Desain Alat Destilasi Laut dengan Sumber Energi Tenaga Surya Sebagai Alternatif Penyediaan Air Bersih.Bogor: Institut Pertanian Bogor.

Efendi. (2003). Telaah Kualitas Air.Bogor : IPB press

Prasetyo, C. H.(2011). Peningkatan Unjuk Kerja Destilasi Air Energi Surya Menggunakan

Reflektor. Skripsi jurusan teknik mesin Fakultas Sains dan Teknologi. Yogyakarta: Universitas Sanata Dharma. 